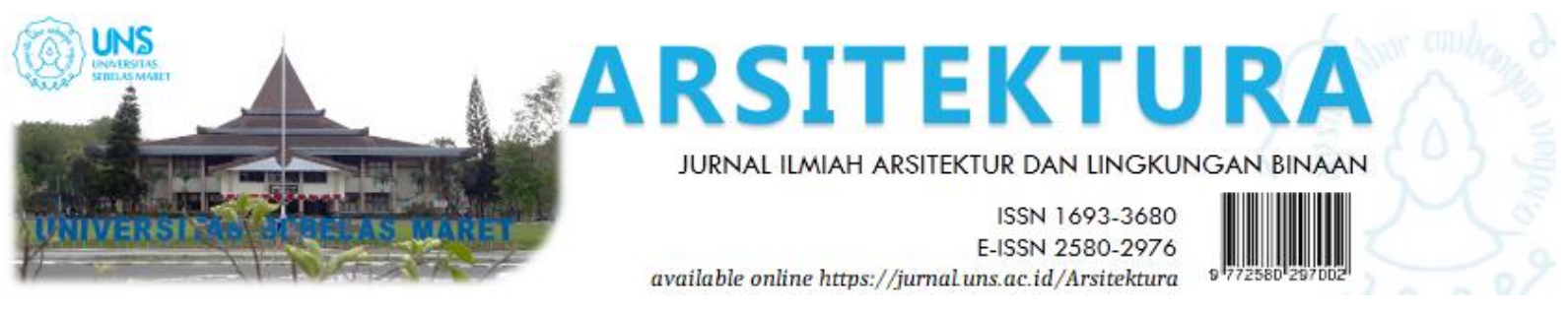

Volume 18 Issue 2 October 2020, pages:249-264

\title{
Dinamika Terbentuknya Wilayah Kampung Arab di Surakarta
}

\section{The Dynamics of Kampung Arab Development in Surakarta}

\author{
Najmi Muhamad Bazher * \\ MENARA, Study and Research Center of Arab Ancestry in Indonesia \\ Email:bazhernajmi@gmail.com*
}

DOI: https://doi.org/10.20961/arst.v18i2.43363

Received:July 28, 2020 Revised: September 17,2020 Accepted: September 18, 2020 Availableonline: October 31, 2020

\begin{abstract}
A majorityof modern-day Arab-Indonesians are the descendant of Hadrama ut immig rants who came to Indonesia. They have stayed and settled in area near eachother that a re now known as kampung Arab. Most kampung Arab in Indonesia show that Arabs had similar pattern in the ir way of settling. Surakarta, as the chosen location, has kampung Arablocated at Pasar Kliwon. There are theories about how these kampung Arab, including Pasar Kliwon, were developed. The objective of this study is to explore the four theories of Kampung Arab Pasar Kliwon development factors and the chronological sequence of those factors. This study is a qualitative research that uses secondary analysis of the previous studies as its method. Data verification utilised trian gulation method, using various approaches, such as observation, interview, and participatorymapping. All four theories are considered valid. Based on the history of Kampung Arab Pasar Kliwon development, thefactors in chronologicalorder are economic activities, community, keraton (imperial) government policy, and colonial govermment policy.
\end{abstract}

Keywords: Arab-Indonesian, district, kampung Arab, Pasar Kliwon, settelement.

\section{PENDAHULUAN}

Mayoritas orang Arab yang kini tinggal di Nusantara adalah keturunan dari imigran Hadramaut yang menetap di Indonesia (Berg, 2010). Wilayah Hadramaut kini menjadi sebuah provinsi di Republik Yaman. Setelah kedatangannya di berbagai kota di Nusantara, para imigran dari Hadramaut cenderung menetap dan bermukim di suatu wilayah dan saling berdekatan. Wilayah tempat orangorang Hadramaut (disebut Hadrami) tinggal lalu dikenal dengan istilah Kampung Arab.

Kampung Ampel di Surabaya, Embong Arab di Malang, Kampung Arab Panjunan di Cirebon, Kampung Empang di Bogor, Kampung Arab Pasar Kliwon di Surakarta, Kampung Arab Al-
Munawar di Palembang, dan Kampung Arab Ampenan di Lombok adalah sedikit contoh Kampung Arab di Indonesia. Terbentuknya klaster permukiman Arab pada berbagai kota di Indonesia, menunjukkan adanya persamaan pola bermukim para imigran Hadramaut.

Terdapat beberapa teori mengenai faktor pemukiman etnis Arab di satu wilayah. Teori pertama, aktivitas ekonomi menjadi faktor terbentuknya permukiman Arab. Hadrami bermigrasi ke Asia Tenggara untuk berdagang dan mencari kehidupan yang lebih baik (Kesheh, 2007). Mereka singgah lalu menetap di berbagai area pusat perdagangan. Hubungan sosial dalam komunitas menjadi teori lain faktor pemukiman etnis Arab. Dijelaskan pula oleh Kesheh (2007), bahwa imigran Hadrami 
cenderung menetap di kawasan tempat saudara atau imigran dari desa yang sama tinggal.

Teori lain adalah peraturan kerajaan sebagai alasan terbentuknya klaster permukiman Arab. Pada periode kerajaan di Indonesia, raja berkuasa atas keseluruhan wilayahnya. Tata ruang di Jawa mengikuti kebijakan keraton (kerajaan) sesuai struktur sosial masyarakat dan kosmologi Jawa (Kusumastuti, 2016b). Teori terakhir yaitu permukiman Arab terbentuk di masa kolonial Belanda. Dijelaskan oleh Priyatmoko (2017), pemukiman etnis Arab mapan berkat politik pemerintah Belanda.

Kajian terhadap teori-teori tersebut dapat dilakukan melalui penelusuran sejarah dan pengamatan pada kondisi eksisting salah satu Kampung Arab di Indonesia, untuk menemukan faktor bermukimnya. Salah satu kota tua di Indonesia yang menyimpan berbagai warisan kebudayaan dari bermacam etnik adalah Surakarta (Prasetyo, 2001). Sehingga Surakarta (Solo) dipilih sebagai lokasi penelitian dan eksplorasi sejarah pemukiman etnis Arab. Di sana terdapat permukiman etnis Arab yang dikenal dengan Kampung Arab Pasar Kliwon. Wilayahnya cukup luas dan terus berkembang hingga sekarang, serta berada di kawasan pusat kebudayaan dan sejarah Solo. Di masa lalu, daerah ini adalah pasar untuk jual beli kambing yang buka pada hari Kliwon (Sajid, 1984).

Terdapat kesimpang siuran teori tentang bagaimana terbentuknya Kampung Arab di Indonesia, termasuk di Surakarta. Sehingga, penelitian ini bertujuan mengkaji kebenaran faktor-faktor terbentuknya dan berkembangnya Kampung Arab Pasar Kliwon di Surakarta dan bagaimana urutannya secara kronologis.

Berdasar analisis Zaida dan Arifin (2010) mengenai perkembangan Kota Surakarta, diperoleh 3 faktor yang menentukan perubahan

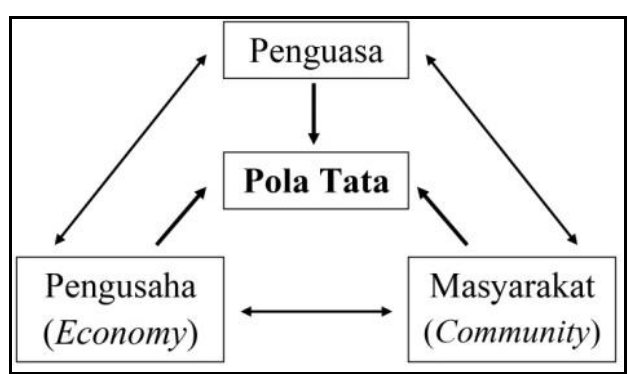

Gambar 1. Faktor yang berpengaruh terhadap tata ruang Kota Surakarta

Sumber: Zaida dan Arifin (2010). tata ruang kota (lihat gambar 1). Pertama adalah perekonomian. Memudahkan aktivitas ekonomi dapat menjadi alasan preferensi bermukim. Keberadaan pengusaha besar juga dapat mempengaruhi tatanan ruang kota. Kedua, kesamaan budaya yang berlaku dalam komunitas (masyarakat) dapat mempengaruhi pola dalam kehidupan sehari-hari, termasuk dalam preferensi bermukim. Ketiga, kebijakan penguasa pada tiap-tiap periode menjadi andil besar dalam pembentukan tata ruang kota.

\section{METODE}

Penelitian mengenai fenomena terbentuknya permukiman etnis Arab di Surakarta, tergolong penelitian kualitatif. Menurut Moleong (2007), penelitian kualitatif adalah penelitian yang bermaksud untuk memahami fenomena tentang apa yang dialami oleh subjek penelitian secara holistik dengan cara deskripsi. Analisis data dilakukan dengan metode analisis sekunder. Hakim (1982) merumuskan analisis data sekunder sebagai analisis lebih lanjut data yang sudah ada, yang memunculkan simpulan tambahan dan atau yang berbeda dari apa yang telah disajikan temuan penelitian terdahulu.

Data sekunder dikumpulkan melalui studi pustaka yang terkait dengan kampung Arab. Selanjutnya, data sekunder diolah dan dieksplor untuk mencapai runtutan sesuai tujuan penelitian.

Selanjutnya dilakukan verifikasi data dengan metode triangulasi. Menurut Denzin (1970), triangulasi adalah pemaduan berbagai sumber data, teori, dan metode dalam suatu penelitian. Triangulasi metode dipilih karena satu dan lain metode akan saling menutup kelemahan sehingga hasilnya menjadi lebih valid. Metode verifikasi yang dimaksud antara lain melalui observasi kawasan Kampung Arab Pasar Kliwon, pemetaan bersama komunitas etnis Arab (participatory mapping), serta wawancara dengan pemerhati komunitas Arab-Indonesia, kerabat keraton yang juga penduduk di Baluwarti, dan komunitas etnis Arab di Solo.

\section{HASIL DAN PEMBAHASAN}

Berdasar data sekunder, terdapat 4 teori faktor terbentuknya Kampung Arab Pasar Kliwon, yaitu aktivitas ekonomi, komunitas, kebijak an kerajaan, dan kebijakan kolonial Belanda. 


\subsection{Faktor Aktivitas Ekonomi}

Aktivitas ekonomi menjadi salah satu teori faktor terbentuknya Kampung Arab. Bagian ini berisi kajian sejarah kegiatan ekonomi imigran Arab di Indonesia, khususnya di Surakarta, dan korelasinya dengan kondisi aktual.

\subsubsection{Migrasi Pedagang Arab ke Indonesia}

Berdasar wawancara pada 17 Juni 2020 dengan Adil Abdullah Albatati, pemerhati komunitas Arab-Indonesia, bangsa Arab datang ke Indonesia sebagai pedagang sejak periode praIslam pada abad ke-4. Kemungkinan titik berangkat mereka dari Negeri Syam, yang artinya asal pedagang bisa beragam seperti dari Syam sendiri, Afrika Utara, Yaman, dll. Pedagang Arab ini masuk ke Kota Barus, Sumatera Utara dan mendirikan permukiman tahun 627-643, yang diketahui sebagai Kampung Arab pertama di Indonesia. Menurut Tibbetts (1956), sejak abad ke-7 mulai tampak rute perdagangan tetap antara Arab Selatan dengan Asia Tenggara.

Mayoritas orang Arab yang kini tinggal di Indonesia adalah keturunan dari imigran Hadramaut yang menetap. Kedatangan imigran Hadramaut dalam jumlah besar yang pertama terjadi pada abad ke-13 hingga 15 (Saefullah, 2013). Eksodus kedua terjadi pada abad ke-17 hingga awal abad ke-20, yang puncaknya terjadi pada awal dan akhir abad ke-19.

Kondisi ekonomi dan politik yang buruk, menyebabkan Hadrami (mayoritas pria) hijrah ke Asia Tenggara untuk mencoba berdagang dan mencari kehidupan yang lebih baik (Kesheh, 2007). Berg (2010) menambahkan, selain karena kondisi politik, turunnya biaya transportasi dan ekspansi kapitalisme kolonial di Indonesia berdampak pada membanjirnya migrasi Hadrami ke Nusantara. Bila pada awal hanya kaum sayid (strata tinggi) dan golongan berekonomi lemah yang bermigrasi, seterusnya disusul golongan berstrata sosial rendah pula.

Disebutkan oleh Kesheh (2007), sejak tahun 1820, kelompok Hadrami mulai menetap di berbagai pusat perdagangan sepanjang pantai Utara Jawa. Jumlah mereka meningkat setel ah dibukanya rute kapal uap antara jazirah Arab dan Indonesia melalui Terusan Suez pada tahun 1869. Beberapa imigran Arab telah menetap di pelabuhan-pelabuhan penting di Nusantara sebelum abad ke-19 (Berg, 2010).

\subsubsection{Kegiatan Ekonomi Imigran Arab dan Keturunannya di Indonesia pada Masa Lalu}

Berg (2010) menjelaskan bahwa jarang ditemui orang Arab yang tidak berminat dengan perdagangan. Sama seperti orang Cina, mereka menjadi pedagang perantara dengan membeli barang dalam jumlah besar, untuk kemudian dijual lagi. Pusat perdagangan golongan Arab yang besar pada masa itu adalah Batavia (kini Jakarta), Semarang, Surabaya, dan Singapura. Di sana mereka membeli komoditas impor dalam jumlah besar. Pedagang besar ini lalu menjual barangnya ke rekan dagang di berbagai tempat dan atau ke penjaja Arab.

Komoditas utama dari pedagang Arab adalah cita katun dan katun India yang diimpor dari Eropa. Komoditas berupa berlian dan batu permata lainnya, dijual pada beberapa tempat di kota besar. Sedikit dari mereka juga menjual komoditas impor berupa barang dari emas dan perak, arloji, makanan yang diawetkan, senjata, tembikar, rempah-rempah, cerutu, minyak tanah, dan sebagainya.

Kebanyakan imigran Arab yang menjadi kaya di Indonesia, memilih untuk tidak pulang karena sudah hidup makmur dan tidak lagi mencintai tanah airnya. Mereka meninggalkan Hadramaut dalam keadaan miskin, lalu merasakan kepuasan hidup di Indonesia yang tak dirasakan sebelumnya (Berg,2010). Karena alasan budaya, beberapa anggota suku harus meninggalkan sedikit kemewahannya, apabila ingin kembali tinggal bersama keluarganya.

\subsubsection{Bandar Perdagangan dan Pemukiman Arab di Surakarta}

Disampaikan oleh Qomarun dan Prayitno (2007), bahwa Kota Surakarta (Solo) pada awalnya dibentuk oleh masyarakat kuli. Pimpinan kuli pelabuhannya bernama Ki Sala (Ki Soroh Bau), yang dijadikan sebagai nama Kota Solo. Mereka membentuk permukiman tepian sungai di sekitar Bengawan Solo, dekat tempat mereka bekerja untuk majikannya yaitu Kadipaten Pajang (sekitar tahun 1530).

Kebutuhan pokok kerajaan tersebut banyak disediakan dari lalu lintas sungai dan bandar dagang di sepanjang Bengawan Solo. Sungai ini menjadi jalur utama perdagangan dan pelayaran yang menghubungkan antara wilayah pedalaman Jawa dengan laut (lihat gambar 2). Kegiatan perdagangan sangat ramai 
hingga terbentuk 44 bandar dagang di sepanjang Bengawan Solo (Kusumastuti, 2016a).

Disampaikan oleh Soedarmono (dalam Hastuti, 2008), bahwa orang Arab dari pantai Utara Jawa datang ke kerajaan di Jawa sebagai pedagang sekaligus menyebarkan agama Islam, dan berlabuh di bandar Bengawan Semanggi (bandar di Bengawan Solo). Para pedagang asing kemudian membuat tempat singgah tetap di setiap bandar untuk menunggu persediaan produk yang akan dibawa, menjual habis produk yang diangkut, maupun untuk menunggu arah angin. Pada perkembangannya, lokasi persinggahan itu berubah menjadi perkampungan orang asing (Kusumastuti, 2016a). Ditekankan oleh Priyatmoko (2017), bahwa pedagang asing (termasuk Arab) di Solo memilih bermukim di sekitar aliran sungai guna memudahkan kegiatan ekonomi.

Kawasan Semanggi sebagai tempat orang Arab di Solo berlabuh, dahulu terbelah oleh dua sungai yaitu Bengawan Solo (sebelah timur) dan Bengawan Semanggi (sebelah barat). Di antara kedua bengawan itu, muncul delta Pulau Semanggi (lihat lampiran 1), yang kemudian disatukan dengan daratan Pasar Kliwon dengan mengurug Bengawan Semanggi (Hastuti, 2008). Di kawasan ini lah orang Arab menetap.

Sekitar tahun 1500 di Solo, terdapat 4 bandar kecil yang ramai, yang dilewati anak sungai Bengawan Solo (lihat lampiran 1) yaitu Bandar Kabanaran di Laweyan, Bandar Pecinan di Kali Pepe, Bandar Arab di Kali Jenes, dan Bandar Nusupan di Semanggi (Qomarun dan Prayitno, 2007). Pada zaman Mataram, saudagar dari Kota Gedhe menuju Gresik dan Surabaya melewati Bandar Nusupan dan Kampung Beton (Sajid, 1984). Kali Jenes tempat Bandar Arab berada, melewati Pasar Kliwon. Sungai ini menghubungkan daerah timur yaitu bekas Kerajaan Kartasura, hingga selatan Surakarta ke Bengawan Solo (Kusumo dkk, 2013).

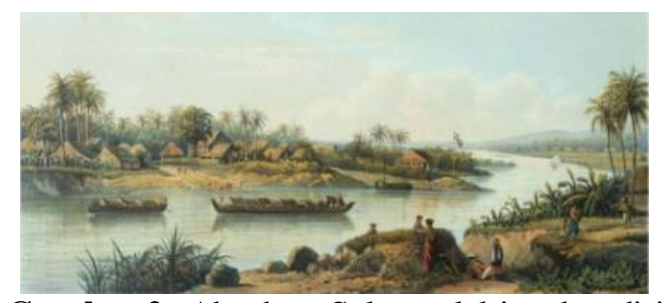

Gambar 2. Abraham Salm melukisan kondisi Bengawan Solo sebagaijalur perdagangan

Sumber: kekunoan.com oleh Agung Nugra ha
Bandar Arab diduga hilang sejak dibangunnya tanggul Kali Wingko dan pintu air Demangan. Akibatnya Kali Jenes menjadi kecil dan dangkal sehingga tidak dapat dilewati perahu (Suryono dan Wiyoko, 2015). Hal ini berimbas pula pada bandar lain di Kota Solo yang tidak dapat berfungsi lagi, dan transportasi air yang tidak lagi ramai sejak tahun 1900-an (Qomarun dan Prayitno, 2007).

\subsubsection{Korelasi dengan Kondisi Aktual}

Korelasi dari sejarah perdagangan orang Arab pada aliran sungai di Surakarta, dapat ditemukan dengan analisis jejak aktivitas perdagangan sekitar sungai dan analisis sistem mata pencaharian etnis Arab di Kampung Arab Pasar Kliwon saat ini. Jejak aktivitas perdagangan di sekitar sungai oleh etnis Arab di Solo ditangguhkan dengan 6 hal yang ditemukan pada kondisi eksisting.

Pertama adalah jejak eksistensi Bengawan Solo sebagai jalur transportasi perdagangan dan penyeberangan di Surakarta. Saat ini terkadang perahu difungsikan kembali untuk menyeberangi Bengawan Solo dari tepian Kampung Beton, apabila air sungai pasang dan jembatan tidak dapat diseberangi (gambar 3).

Kedua adalah keberadaan Kampung Beton (lihat lampiran 1). Nama kampung ini diambil dari Bandar Beton, salah satu bandar strategis yang merupakan tempuran alur Bengawan Solo dengan Kali Pepe. Nama itu muncul dari ucapan warga kepada awak kapal, yaitu "mbetane napa mawon?" yang artinya membawa apa saja. Di sini pula VOC membangun pergudangan.
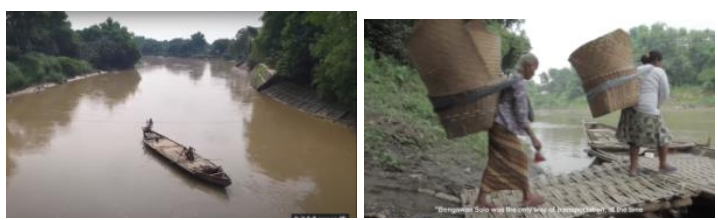

Gambar 3. Jejak Bengawan Solo sebagaijalur penyeberangan dan perdagangan

Sumber: https://www.youtube.com/watch?v= O6OUh8NQ7Y0\&t=13s

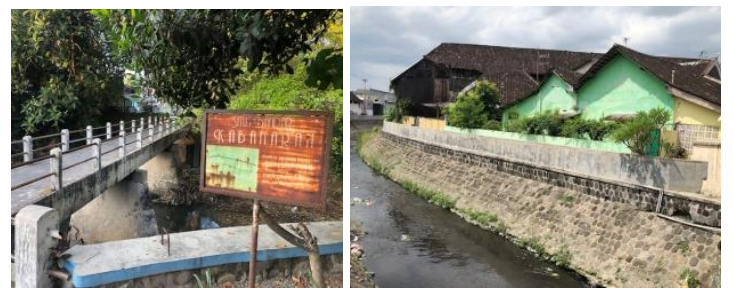

Gambar 4. Situs Bandar Kabanaran diLaweyan (kiri) dan Kali Jenes di Pa sar Kliwon (kanan) 
Ketiga adalah keberadaan situs Bandar Kabanaran pada tepian Kali Jenes di Laweyan (gambar 4). Keempat adalah keberadaan Kali Jenes sendiri yang dikenal sebagai Bandar Arab. Sungai ini terhubung dari situs Bandar Kabanaran di Laweyan dan bercabang menuju daerah (bandar) Nusupan atau menuju (bandar utama) Semanggi yang melewati Bandar Arab di Pasar Kliwon (lampiran 1). Kelima adalah keberadaan Kali Pepe yang dikenal sebagai Bandar Pecinan, serta keberadaan permukiman etnis Cina di sekitarnya. Poin ketiga, keempat, dan kelima menguatkan sejarah perdagangan melalui aliran sungai di Solo.

Keenam adalah kesamaan karakter lokasi Kampung Arab Pasar Kliwon dengan Kampung Arab lain di Indonesia, berupa waterfront settlement, yaitu permukiman di tepi perairan. Contoh Kampung Arab lain yang berdekatan dengan sungai atau pelabuhan yaitu Kampung Arab Ampel Surabaya berada di antara Sungai Pegirian dan Sungai Kalimas, Kampung Arab di Malang berdekatan dengan sungai, Kampung Arab Panjunan di Cirebon berdekatan dengan pelabuhan, Kampung Arab Pekojan (dahulu area khoja/muslim India) di Jakarta berbatasan dengan Kali Krukut, Kampung Empang di Bogor berbatasan dengan Sungai Cisadane, Kampung Arab Al-Munawar di Palembang berada di tepin Sungai Musi, Kampung Arab di Lombokberada di bekasdermaga Ampenan, dan Kampung Arab di Singaraja berdekatan dengan dermaga. Dari beberapa contoh tersebut, dapat disimpulkan bahwa imigran Hadramaut cenderung memilih bermukim di dekat sungai atau dermaga, yang menjadi jalur transportasi perdagangan di masa lampau.

Sejarah perdagangan imigran Arab di Solo, dapat diperkuat dengan melihat adanya 3 persamaan sistem mata pencaharian etnis Arab, pada masa lalu dengan sekarang. Pertama adalah komoditas utama etnis Arab di Pasar Kliwon kini, yaitu kain, sama seperti pada sejarah. Tidak hanya menjualnya, banyak dari mereka yang mempunyai pabrik pengolahan kain. Selain pabrik kain, ada pula pabrik sarung Goyor. Sarung merupakan pakaian tradisional Yaman yang diadaptasi di Indonesia.

Pada perkembangannya, beberapa pabrik kain dan sarung milik etnis Arab pindah dari Pasar Kliwon atau-pun bangkrut. Beberapa pemilik memilih untuk menjual pabrik di Pasar Kliwon dengan harga tinggi, lalu membangun pabrik yang lebih luas di kabupaten sekitar Solo. Pabrik milik etnis Arab yang merupakan bisnis turun-temurun sering kali bangkrut, karena anaknya tidak mampu mengelola, atau memilih bekerja di bidang lain, atau pindah ke tempat lain dan menelantarkan bisnis keluarga.

Kedua adalah mata pencaharian utama etnis Arab di Pasar Kliwon, yaitu berdagang, sama dengan imigran Arab. Selain karena merupakan bisnis turun-temurun, etnis Arab cenderung memilih membuka usaha dengan berdagang, karena menginginkan kebebasan bekerja yang tak terikat oleh aturan. Selain kain, komoditas terbanyak adalah produk khas Arab seperti kurma, herbal, parfum, henna, perlengkapan ibadah, dsb. Pemetaan pabrik kain dan sarung, toko produk Arab, dan usaha etnis Arab lain di Pasar Kliwon dapat dilihat pada lampiran 2.

Ketiga, jaringan kekerabatan yang pada masa lalu dilakukan para imigran Arab untuk saling membantu kondisi ekonomi (dijelaskan pada 3.2.1), terlihat pula pada modern ini di Kampung Arab Pasar Kliwon. Salah satu mangsa pasar etnis Arab adalah komunitasnya sendiri, dan promosi terjadi dari mulut ke mulut dalam komunitas melalui jejaring kekerabatan. Tidak heran bila etnis Arab akhirnya banyak yang membuka bisnis rumahan di sini, khususnya dalam bidang kuliner. Dukungan bisnis oleh komunitas seperti ini yang membuat etnis Arab tertarik dan betah tinggal di Pasar Kliwon hingga sekarang.

Kajian 6 temuan fisik pada kondisi eksisting menjadi bukti jejak aktivitas perdagangan etnis Arab Solo di sekitar sungai. Berdasarkan kajian sejarah kedatangan pedagang Arab dan bandar dagangnya di Solo, dapat disimpulkan bahwa ekonomi menjadi faktor utama dan pemicu terbentuknya pemukiman Arab di Solo. Kajian mengenai mata pencaharian etnis Arab di Pasar Kliwon menunjukkan kesamaan karakter dengan sejarah, dan menjadikan ekonomi sebagai faktor berkembangnya Kampung Arab Pasar Kliwon dari masa lalu hingga sekarang.

\subsection{Faktor Komunitas}

Teori lain mengenai pemukiman Arab di Surakarta adalah terbentuk karena faktor komunitas. Pada bagian ini akan dikaji sejarah mengenai hubungan sosial imigran Arab di Indonesia, serta korelasinya dengan kondisi aktual di Surakarta. 


\subsubsection{Kondisi Sosial Imigran Hadramaut}

Saat bermigrasi ke Indonesia, Hadrami lebih memilih tinggal di kawasan di mana mereka dapat menemukan kerabat atau imigran lain dari desa yang sama di tanah airnya (Kesheh, 2007). Van den Berg (2010) menjelaskan bahwa imigran yang baru datang dianggap sebagai tamu oleh orang Arab yang mengundangnya. Jika datang dengan kehendak sendiri, imigran Arab akan meminta salah satu anggota keluarga atau suku untuk menampungnya. Jarang ada imigran Arab yang datang ke Indonesia tanpa mengenal seseorang yang diharapkan dapat menampungnya. Terkadang mereka bersamasama membeli rumah, karena tidak mendapat penampungan dan belum bisa membeli rumah sendiri. Walaupun saat di Hadramut mereka hanya mengelompok dengan sukunya, kesamaan tanah air dan perasaan terasingkan di Indonesia membuat mereka bersatu.

Selain memberikan rasa keakraban, bermukim bersama komunitas juga penting dalam hal mencari pekerjaan. Van den Berg menjelaskan, bahwa terdapat pola aktivitas ekonomi imigran Hadrami pada akhir abad ke-19, yaitu para pendatang akan bekerja sebagai asisten toko milik keluarga atau kenalannya yang menetap lebih dulu di Indonesia (Kesheh, 2007). Selain itu, apabila kesulitan menjalankan usahanya sendiri, mereka akan meminta pemuda dari keluarga atau sukunya untuk datang dan bekerja untuknya. Karena pola tersebut, sebagian besar imigran Arab berasal dari tempat yang sama, yaitu Hadramaut (Berg, 2010). Berdasar wawancara dengan Adil Abdullah Albatati, dijelaskan bahwa pola tersebut di atas sudah berlangsung sejak lama, bahkan sebelum eksodus imigran Hadramaut kedua. Dalam bermigrasi-pun, mereka melakukannya secara bersama dalam jumlah yang relatif kecil, berupa kelompok dagang. Pola bertahan hidup secara komunal ini sudah menjadi budaya mereka.

Terdapat upaya untuk saling menjaga ikatan antara imigran dengan kerabat di tanah airnya. Banyak diantara imigran Hadramaut yang datang ke Indonesia, dengan tujuan berjumpa dengan kerabat dan keluarga (Ridwiyanto, 2011). Saat menjadi kaya di Indonesia, mereka tidak melupakan keluarga serta sahabat di tanah airnya, dan mengiriminya uang dengan menitipkan kepada kerabatnya yang akan pulang (Berg, 2010). Hal ini dikarenakan orang Arab sangat menghormati orang tuanya dan memiliki gagasan bahwa kekayaan harus dinikmati seluruh keluarga.

Imigran Hadramaut gelombang pertama dan kedua terdiri dari kaum pria yang kemudian menikahi wanita setempat. Yang berbeda adalah golongan gelombang pertama biasanya melakukan asimilasi penuh dan menggunakan nama lokal, sedangkan golongan gelombang kedua berusaha menjaga identitas Hadrami-nya (Saefullah, 2013). Memiliki isteri kelahiran Indonesia yang tidak siap hidup di negeri asing menjadi salah satu alasan Hadrami tidak pulang ke tanah airnya (Berg, 2010).

\subsubsection{Korelasi dengan Kondisi Aktual}

Korelasi dari sejarah sistem sosial Hadrami di Indonesia dengan kondisi aktual etnis Arab di Surakarta, dapat ditemukan dengan eksplorasi 7 persamaan sistem hubungan sosialnya. Pengaruh sosial budaya komunitas Arab terhadap perkembangan wilayah Kampung Arab, akan dibahas pula pada bagian ini.

Persamaan pertama sistem sosial antara etnis Arab di masa lalu dengan kondisi aktual di Pasar Kliwon, adalah pola bermukim secara komunal. Masyarakat etnis Arab di Surakarta hidup berkumpul di tempat yang saling berdekatan. Salah satu alasannya yaitu untuk memudahkan interaksi sosial dalam komunitas. Mereka memiliki kebiasaan untuk berkumpul dan bercengkerama dengan kerabat, tetangga, serta teman sesama peranakan Arab (Bazher, 2017). Bila memungkinkan, para pria biasa berkumpul tiap malam di salah satu rumah mereka atau di ruang publik. Sedangkan para wanita bersilaturahmi dengan melakukan arisan (keluarga, tetangga, marga, kelompok teman) sekaligus kajian agama (Bulkia, 2012).

Persamaan kedua adalah keramah tamahan dalam menerima tamu, sama seperti imigran Arab dalam menampung pendatang baru. Seringnya antar mereka bertamu, dilakukan untuk menjaga tali silaturahmi. Budaya ini yang membuat orang tua tidak merasa kesepian dan betah tinggal di Kampung Arab. Banyak diantaranya yang lebih senang menampung tamu jauh di rumah, dibanding membiarkannya di penginapan. Menjamu tamu dengan sebaik mungkin sudah menjadi budaya etnis Arab.

Persamaan ketiga adalah eratnya hubungan di dalam komunitas Arab, masa lalu dan kini. 
Etnis Arab menganggap orang sesama etnisnya sebagai saudara. Mereka akan saling menyapa bila bertemu walau belum saling mengenal. Mereka terbiasa saling merangkul dan mencium pipi saat bertemu dengan saudara dan temannya. Klub bola Fatah FC merupakan salah satu contoh forum komunitas yang didirikan oleh etnis Arab di Solo.

Ketiga karakter sosial di atas, dapat dilihat pula dalam bentuk fisik pada elemen rumah ting gal etnik Arab. Mayoritas rumah etnik Arab memiliki ruang keluarga yang luas dengan karpet untuk berkumpul dan berbincang. Ruang ini digunakan pula untuk menerima tamu akrab dan keluarga. Pada rumah tua di Pasar Kliwon, biasa ditemukan pintu penghubung ke rumah tetangga di area belakang rumah (Bazher, 2018). Rumah tua tersebut sebelumnya tidak dan atau berpagar pendek yang berkesan menerima. Walau pada perkembangannya banyak yang diubah dengan pagar tinggi (dijelaskan pada poin 3.4.3).

Persamaan keempat adalah jejaring kekerabatan pada komunitas etnis Arab di Pasar Kliwon dalam hal ekonomi. Sama halnya dengan para imigran yang mendatangkan kerabatnya untuk membantu usahanya, etnis Arab terkadang mempekerjakan kerabat sesama etnis sebagai orang kepercayaan pada bisnisnya. Bagaimana jejaring kekerabatan membantu pemasaran telah disampaikan pada 3.1.4.

Persamaan kelima adalah kedekatan hubungan dengan orang tua dan keluarga pada Hadrami, yang tampak pula pada kondisi aktual di Solo. Etnis Arab memilih tinggal di Pasar Kliwon agar tetap dekat dengan orangtua dan keluarga, sehingga memudahkannya untuk menengok dan silaturahmi secara berkala. Pola bermukim seperti ini menjadi salah satu sebab luas wilayah Kampung Arab Pasar Kliwon terus berkembang hingga sekarang. Ditemukan pula foto dan lukisan orang tua/moyang dari Hadramaut pada beberapa rumah etnik Arab di Solo. Penggunaan silsilah keluarga sebagai hiasan dinding mirip dengan kondisi di Yaman (Bazher, 2018).

Persamaan keenam adalah pentingnya klan bagi imigran Arab, yang terlihat pada kondisi masa kini dalam penggunaan nama marga etnis Arab di Surakarta. Nama marga yang diturunkan dari pihak ayah disertakan pada bagian akhir nama. Penggunaan nama marga memudahkan seseorang untuk dikenali (Bazher, 2017). Setiap berkenalan dengan sesama etnis Arab, biasa ditanyakan berasal dari marga apakah orang tersebut. Dengan eratnya jejaring kekerabatan etnis Arab, memungkinkan mereka mengenal satu sama lain dalam komunitas dan saling berhubungan melalui nama marga.

Persamaan ketujuh adalah rasa ingin menjaga identitas Hadrami, yang terlihat pula pada sistem pernikahan etnis Arab di Surakarta pada masa kini. Mayoritas dari mereka menikah dengan sesama etnis Arab. Selain terjadi karena faktor sosial dan wilayah, pernikahan sesama etnis Arab dilakukan untuk menjaga identitas Hadrami dan karena adanya kesamaan budaya. Menikahkan anak gadis etnis Arab dengan non-Arab dihidari, karena keturunannya tidak akan memiliki nama marga dan kehilangan identitas Arab. Ditakutkan pula apabila menikah dengan non-Arab, maka anak memiliki dua identitas etnik dan kemungkin an meninggalkan budaya Arab.

Selain 7 karakter sosial yang berkorelasi dengan sejarah, terdapat pula faktor budaya yang berpengaruh terhadap perkembangan wilayah Kampung Arab Pasar Kliwon hingga sekarang. Terdapat kesamaan budaya dan pola kehidupan sehari-hari yang hidup di dalam komunitas etnis Arab. Dengan itu, tersedia fasilitas sosial untuk kebutuhan pendidikan dan kegiatan keagamaan mereka, yang disediakan sendiri oleh komunitas Arab tersebut.

Di sisi lain, terdapat kekhawatiran akan terjadinya kesenjangan budaya dan susah beradaptasi bila keluar dari kawasannya. Perbedaan dalam cara berbicara, bercanda, dan berpakaian etnis Arab adalah beberapa contoh hal yang dikhawatirkan dapat mempersulit sosialisasi di luar kawasannya. Walau pada aktualnya Kampung Arab bukan permukiman eksklusif, namun etnis lain di sini sudah membaur dengan etnis Arab.

Kampung Arab yang dahulu hanya berada di Kelurahan Pasar Kliwon dan Kedung Lumbu (lampiran 6), kini berkembang ke dua kelurahan lain yaitu Semanggi dan Joyosuran (lampiran 3). Tingginya minat etnis Arab untuk tinggal di Kampung Arab Pasar Kliwon menyebabkan tingginya harga tanah di kawasan ini. Hal ini dinilai tak sebanding melihat kondisi area dengan jalan sempit dan rawan banjir. 
Banyaknya persamaan antara sejarah dengan kondisi aktual pola hubungan sosial dalam komunitas Arab di Surakarta, menguatkan teori bahwa komunitas menjadi faktor terbentuknya Kampung Arab. Dengan melihat kronologinya, disimpulkan bahwa komunitas menjadi urutan kedua faktor terbentuknya Kampung Arab, setelah faktor ekonomi. Kajian kondisi aktual sosial budaya menunjukkan budaya dalam komunitas menjadi faktor berkembangnya Kampung Arab Pasar Kliwon hingga saat ini.

\subsection{Faktor Kebijakan Keraton}

Teori berikutnya adalah kebijakan oleh keraton sebagai faktor asal mula terbentuknya Kampung Arab di Surakarta. Pada bagian ini akan dikaji sejarah kekuasaan Keraton Kasunanan, kebijakan tata ruang kotanya, serta korelasinya dengan kondisi aktual di Surakarta.

\subsubsection{Kekuasaan Keraton Kasunanan}

Seperti yang telah dituliskan pada poin 3.1.3, para kuli yang tinggal di tepi Bengawan Solo bekerja untuk majikannya di Kadipaten Pajang pada tahun 1530-an. Secara singkat, Kadipaten Pajang pindah ke Kota Gedhe pada tahun 1582 dan menjadi Kasultanan Mataram, lalu pindah ke Kartasura pada tahun 1677 (Qomarun dan Prayitno, 2007). Kemudian terjadi perpecahan dengan adanya 2 raja akibat campur tangan VOC. Kekacauan politik ini diselesaikan dengan pembagian wilayah Mataram menjadi Kasultanan Ngayogyakarta dan Kasunanan Surakarta Hadiningrat. Kasunanan dengan wilayah kekuasaan di Surakarta, secara resmi mulai ditempati tanggal 17 Februari 1745.

Dalam artikel berjudul Hak dan Kewajiban Raja sebagai Titisan Dewa, Risa H. Putri menyampaikan, bahwa raja-raja terdahulu mengaku sebagai titisan dewa untuk mengesahkan kekuasaanya. Diceritakan pada Babad Tanah Jawi (dalam Kurniawan, 2011), Pangeran Puger (Paku Buwono I) menjelaskan bahwa raja adalah "warananing Allah", yaitu wakil atau penjelmaan Tuhan. Dijelaskan lebih lanjut bahwa segala sesuatu di tanah Jawa, air, rumput, daun, dan lainnya di atas bumi adalah milik raja. Sehingga orang Jawa menganut konsep kekuasaan yakni tidak ada sikap lain yang harus diambil kecuali "ndherek ngarsa dalem", yang berarti terserah kehendak raja.

Pada masa kerajaan di Surakarta, semua tanah pada wilayah kekuasaan dianggap milik raja, sementara rakyat hanya memakainya. Menurut Kurniawan (2011), otoritas Kasunanan dalam mengatur wilayahnya serta tunduknya rakyat terhadap aturannya, dikarenakan keraton memiliki kekuasaan dan kekayaan sumber daya kehidupan, seperti tanah, kedudukan, politik, dan budaya. Menurut Roll (dalam Karjoko, 2005), sejak masa kolonial, Keraton Kasunanan menjadi satu-satunya pemilik seluruh tanah pada wilayah kekuasaan kerajaan.

Selain tanah yang digunakan raja, dinamakan tanah lungguh/gaduh/apanase, yaitu tanah yang dipergunakan sementara oleh para sentana yang memiliki hubungan kekerabatan dekat dengan raja, serta oleh abdi dalem selama mereka memegang jabatan (Kurniawan, 2011). Keraton mengizinkan mereka tinggal di tanah keraton sebagai balas jasa, hadiah, atau gaji untuk mereka. Bila hubungan kekerabatan terputus dan atau tidak lagi menjabat di keraton, maka tanah yang dipakainya akan kembali kepada raja. Ada pula yang diberi wewenang "Anggaduh Run Temurun", yaitu hak atas tanah untuk dipakai turun temurun.

\subsubsection{Tata Kota Kosmologi Jawa}

Pada masa kerajaan di Jawa, diberlakukan kebijakan tata kota yang didasarkan pada kelas sosial. Struktur sosial masyarakat Jawa terdiri dari sentono dalem (sentana/keluarga pemimpin kerajaan), abdi dalem (pegawai kerajaan), dan kawulo dalem (berhubungan darah dengan keluarga kerajaan) (Mulyadi, 1999). Pembagian kelas sosial tersebut membentuk tata ruang kota, di mana tempat tinggal raja menjadi pusatnya. Kondisi ini sesuai dengan struktur kosmos, yaitu dewa/tuhan berada di tengah-tengah dan dikelilingi rakyat (Kusumastuti, 2016b).

Santoso (dalam Junianto, 2019) menjelaskan bahwa stuktur kota Jawa pada zaman kerajaan sesuai dengan konsep kosmologi Jawa, yang terbagi menjadi 5 lingkaran dengan fungsi keruangan sakral dan profan, yaitu dalem, komplek keraton, nagara, nagara agung, dan mancanagara. Sedangkan Soemardjan (dalam Zaenurrosyid, 2013) menjelaskan bahwa konsep ruang negara di Jawa terdiri dari 4 ruang lingkaran yaitu keraton (parentah njero), nagara (parentah njaba), nagaragung, dan mancanagara. Gabungan dari kedua toeri tersebut dapat dilihat pada gambar 5 .

Pertama adalah keraton (parentah njero) sebagai tempat administrasi dalam, yang terdiri 
dari (1a) dalem yaitu tempat tinggal raja dan pusaka, dan (2a) kompleks keraton yaitu batas benteng keraton yang di dalamnya terdapat permukiman sentan, pegawai (abdi dalem), dan prajurit dalam. Kedua adalah nagara (parentah njaba), yaitu pusat adminitrasi dan pemerintahan. Di sini terdapat pula alun-alun, masjid, dan tempat permukiman pejabat istana, prajurit (patih), serta pangeran. Ketiga adalah naragung atau nagaragung, sebagai kota besar terdiri dari kawasan tanah lungguh, yang dipakai sentana dan abdi dalem. Tanah narawita yaitu tanah yang menghasilkan produk tertentu untuk kepentingan raja dan kerajaan juga berada di sini. Keempat adalah mancanegara, yaitu negara asing yang ditaklukkan oleh raja.

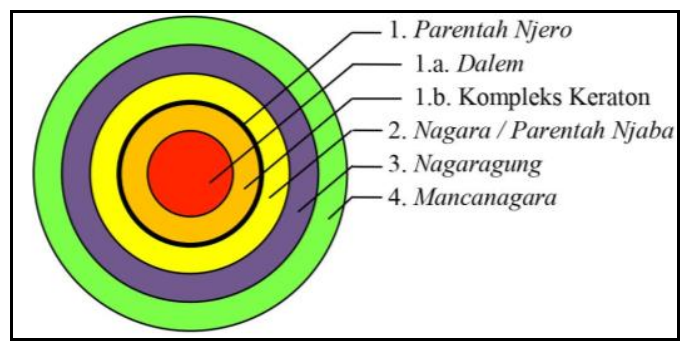

Gambar 5. Konsep ruang kosmologi Ja wa Sumber: AdaptasidariSantoso, 1984 dan Soemardjan, 1991.

\subsubsection{Kebijakan Tata Kota oleh Kasunanan}

Sama dengan konsep kerajaan Jawa, Keraton Kasunanan memberlakukan kebijakan tata kota berdasar struktur sosial masyarakat dan kosmologi Jawa (Kusumastuti, 2016b). Raja, keluarga raja, dan pusaka bertempat tinggal di keraton yang menjadi pusat Kota Surakarta. Pada konsep kosmologi Jawa, area ini menjadi lingkaran pertama dan disebut ruang dalem yang menjadi bagian dari parentah njero (lihat lampiran 4). Lingkaran berikutnya yang masih menjadi bagian dari parentah njero adalah kompleks keraton yaitu Baluwarti (bahasa Portugis: Baluwarte), yang berarti tembok atau benteng. Area ini berada di luar istana dan dikelilingi dinding tinggi pada bagian luarnya. Di sini tinggal kerabat dekat raja, abdi dalem, dan prajurit dalam. Prajurit tersebut antara lain golongan Wiratamtama yang daerah tinggalnya disebut Kampung Tamtaman, dan golongan Carangan yang kawasan tinggalnya dikenal dengan Kampung Carangan.

Nagara yang merupakan lingkaran berikutnya adalah pusat administrasi atau ibu kota kerajaan. Di area ini ada kompleks Kepatihan yang terdiri dari perkantoran, tempat tinggal patih, dan hunian abdi dalem Kepatihan. Masjid Agung dan alun-alun sebagai area sakral keraton termasuk dalam lingkaran ini.

Naragung menjadi lingkaran berikutnya yang mayoritas merupakan tanah lungguh. Kawasan tempat tinggal abdi dalem berjabatan bupati, diberi nama sesuai nama bupatinya, antara lain Kampung Sewu, Kartadipuran, Penumping, Jayadiningratan, dan Mangkuyudan. Daerah permukiman prajurit dinamai sesuai golongannya, seperti Kampung Saragenen, Jayasuran, dan Jayatakan. Wilayah tempat tinggal abdi dalem pertukangan atau kriya biasa diberi nama dari hasil kriyanya, seperti Baturana (tukang batu), Gemblegan (tukang gemlak/kuningan), dan Sayangan (tukang saying/tembaga). Sebagian tanah tersebut adalah narawita, salah satunya adalah Kampung Gajahan yang merupakan kandang gajah peliharaan di masa lalu. Pasar Gedhe dan pasar tradisional lain termasuk pada zona ini (Aliyah, dkk, 2015).

Permukiman etnis asing juga berada di area ini. Permukiman orang Arab sebagai etnis asing dikelompokkan sendiri dan terpisah dari penduduk lainnya (Mulyadi, 1999). Mereka berada di kanan-kiri Pasar Kliwon, ke selatan hingga Baturono, tepat berada di timur keraton (Sajid, 1984). Etnis Cina berada di Pecinan yaitu daerah Ketandhan, Balong, hingga Warung Pelem. Lokasi permukiman etnis Arab dan Cina tetap berada dekat dengan lokasi bandarnya. Permukiman Belanda berada di Lojiwetan (dijelaskan pada 3.4.3). Keraton tidak menjual tanah kepada etnis asing, sehingga mereka harus menyewa tanah dengan hak bangunan (hak opstal) (Setiawati, 2011).

\subsubsection{Korelasi dengan Kondisi Aktual}

Korelasi antara sejarah kuasa dan kebijakan Keraton Kasunanan dengan kondisi aktual, dapat dilihat dengan analisis kondisi kekuasaan dan tata kota di Surakarta saat ini. Terdapat 3 hal yang disoroti dalam analisis kekuasaan keraton pada kondisi aktual.

Pertama adalah status wilayah kekuasaan keraton. Dengan adanya Keraton Kasunanan dan Mangkunegaran di Surakarta, sejak masa kolonial kota ini dianggap sebagai swapraja atau vorstenlanden, yaitu daerah yang berhak memerintah daerahnya sendiri. Belanda tetap memberikan kekuasaan tanah pada kerajaan yang diakuinya. Pada masa penjajahan Jepang 
pun Surakarta tetap menjadi daerah istimewa dengan sebutan Kochi (Muhafizga, 2014). Pada 19 Agustus 1945, setelah kemerdekaan, Surakarta dinyatakan oleh Presiden Soekarno sebagai Daerah Istimiewa Surakarta yang terdiri dari Daerah Istimewa Kasunanan dan Daerah Istimewa Mangkunegaran.

Muncul gerakan anti-swapraja yang memicu kekacauan di Surakarta. Pada 16 Juli 1946, Daerah Istimewa Surakarta diambil alih sementara oleh pemerintah Indonesia dan dijadikan karisidenan sampai kondisi kembali kondusif. Perubahan ini didasarkan pada penetapan pemerintah no.16/SD 1946. Dijelaskan oleh Bambang H. (dalam Kurniawan, 2011), bahwa mulai saat itu tidak ada pemerintahan keraton, dan wilayah kuasanya menjadi bekas swapraja yang bergabung denganIndonesia. Sempat dilakukan pengajuan kembalinya Daerah Istimewa Surakarta pada tahun 2013 namun hasilnya ditolak.

Poin kedua yang diamati adalah kekuasaan raja. Daerah Istimewa Yogyakarta kini dipimpin Raja Kasultanan Ngayogyakarta sebagai gubernur, dan Raja Kadipaten Pakualaman sebagai wakilnya. Berbeda dengan Surakarta yang dipimpin oleh wali kota, sedangkan Raja Keraton Kasunanan dan Mangkunegaran kini hanya sebagai kepala istana dan kepala adat.

Dualisme kepemimpinan antara pemerintah dan keraton pun terjadi di tanah Keraton Kasunanan. Berdasar Kepres Nomor 23 tahun 1988 pasal 1, tanah dan bangunan Keraton Surakarta berikut segala kelengkapan di dalamnya (termasuk Masjid Agung dan alunalun) adalah milik Kasunanan Surakarta Hadingingrat yang perlu dilestarikan sebagai peninggalan budaya bangsa. Bila berpedoman pada undang-undang tersebut, maka kawasan Baluwarti yang secara adat berada di dalam tembok keraton adalah milik Keraton Surakarta dan berhak dikuasai oleh keraton (Kurniawan, 2011). Namun pada kondisi aktual, Baluwarti menjadi salah satu kelurahan di Surakarta yang merupakan bagian dalam sistem pemerintahan negara.

Poin terakhir adalah kekuasaan tanah keraton. Terdapat ambiguitas hak kepemilikan tanah keraton. Berdasar Kepres No.23 tahun 1988, Baluwarti menjadi wilayah kekuasaan keraton, seperti yang disebutkan sebelumnya. Sedangkan berdasar UUPA No. 5 tahun 1960, sejak berlakunya UU ini, hak dan wewenang atas sumber daya alam dari swapraja atau bekas swapraja dihapus dan beralih ke negara.

Baluwarti merupakan tanah lungguh dan berdasar Palilah Griya Pasiten (perizinan tanah dan bangunan Keraton Surakarta), tidak boleh melaksanakan jual beli atau sewa sebagian atau seluruhnya atas bangunan tersebut. Namun kenyataannya, hal ini terjadi dan banyak pendatang di Baluwarti yang tidak berhubungan dengan keraton menjadi penduduk. Bahkan terdapat 3 ndalem pangeran di Baluwarti, yang bersertifikat hak milik atas nama keluarga Soeharto (Karjoko, 2005).

Selain menyoroti kekuasaan keraton, dianalisis pula tata Kota Surakarta pada kondisi aktual dengan mengacu kebijakan keraton terdahulu. Berdasar wawancara pada 26 Juni 2020 dengan Dinasti Purnomo Putri Suga, seorang kerabat keraton yang juga penduduk di Baluwarti, dijelaskan bahwa mayoritas penduduk Baluwarti sekarang merupakan kerabat dari keraton. Namun banyak pula orang luar yang tinggal di kawasan ini. Sedangkan abdi dalem yang dahulu banyak tinggal di sini, kini jumlahnya berkurang dan lebih banyak tinggal di luar Baluwarti.

Kondisi di Baluwarti menunjukkan bahwa kebijakan tata kota yang dahulu diberlakukan, kini tidak dijalankan dengan tegas di dalam tembok keraton sendiri. Sedangkan di luar area keraton, masyarakat sudah bebas menempati wilayah manapun di Surakarta sebagai permukimannya. Namun penamaan jalan, kampung, dan kelurahan masih menggunakan penamaan yang sama dengan masa kerajaan.

Permukiman etnis Arab dan Cina sekarang masih berada di lokasi yang sama dengan penetapan lokasi di masa kerajaan. Pecinan masih berada di daerah Ketandhan, Balong, hingga Warung Pelem, berlokasi di sekitar Kali Pepe yang merupakan bekas bandar dagang etnis Cina. Begitu pula permukiman etnis Arab yang masih berada di kawasan Pasar Kliwon. Berdasar pemetaan rumah tua milik etnis Arab (lampiran 6) di Pasar Kliwon, lokasinya tidak berada di tepian Kali Jenes (bekas bandar Arab), namun berada tepat di timur tembok keraton. Hal ini diperkirakan karena kebijakan dari keraton yang berkuasa pada masa itu, dan sedikit mustahil bila itu kebijakan Belanda yang menolak berbaurnya etnis Arab dengan keraton. 
Walaupun Keraton Kasunanan Hadiningrat kini tak memiliki kekuasaan seperti terdahulu, namun keberadaan penginggalannya hingga sekarang menjadi bukti sejarah kekuasaan keraton. Nama jalan, kampung, dan kelurahan di Surakarta yang berasal dari jabatan dan karya abdi dalem keraton menangguhkan adanya kebijakan tata kota oleh keraton. Dapat disimpulkan bahwa kebijakan keraton menjadi salah satu faktor kuat terbentuknya klaster permukiman etnis Arab di Surakarta. Kebijakan oleh keraton menjadi urutan ketiga dari faktor terbentuknya Kampung Arab, melihat kronologis periode kekuasaan keraton di Surakarta yang baru mulai tahun 1745 .

\subsection{Faktor Kebijakan Belanda}

Teori terakhir mengenai alasan terbentuknya Kampung Arab di Surakarta adalah karena faktor kebijakan Belanda di masa penjajahan. Pada bagian ini akan dikaji sejarah mengenai kekuasaan Belanda di Indonesia, khususnya di Surakarta, sentimen terhadap etnis Arab dan kebijakan segregasi, serta korelasinya dengan kondisi aktual di Surakarta.

\subsubsection{Kekuasaan Belanda di Surakarta}

Pengaruh Belanda di Indonesia sudah mulai sejak munculnya VOC (Persekutuan Perusahaan Hindia Timur), yang terbentuk pada 20 Maret 1602. Pada 31 Desember 1799, kekuasaan VOC jatuh dan berdampak pada perubahan struktur pemerintahan Indonesia menjadi negara jajahan Belanda, yang wilayahnya dikenal sebagai Hindia Belanda.

Seperti yang disebutkan pada poin sebelumnya, karena keberadaan Keraton Kasunanan dan Mangkunegaran, Surakarta menjadi daerah swapraja pada masa kolonial. Hubungan antara keraton dan pemerintah Belanda diatur dalam perjanjian politik yang disebut politiek contract. Menurut penjelasan Dwi Ratna Hajarini, dkk (dalam Rosiana, 2013), terdapat dua macam perjanjian politik untuk daerah swaparaja, yaitu kontrak panjang (lang contract) dan pernyataan pendek (korte verklaring). Keraton Kasunanan diatur dalam kontrak panjang yang menyatakan kesetaraan kekuasaan antara keraton dengan pemerintah Belanda (Muhafizga, 2014). Sedangkan Mangkunegaran diatur dalam kontrak pendek yang berisi keterangan tentang pengakuan keraton atas kekuasaan Belanda.
Walaupun menjadi daerah otonom, namun dalam praktiknya, keraton tidak lepas dari pengawasan pemerintah Belanda. Untuk mengawasi pemerintahan Keraton Kasunanan, pemerintah Belanda menempatkan seorang residen di Surakarta, dan asisten residen di tiap kabupatennya (Rosiana, 2013). Pemerintah Belanda menguasai Surakarta secara tidak langsung, dengan mengontrol penguasa daerah. Struktur pemerintahan Pakubuwono X di Surakarta dapat dilihat pada gambar 6.

\subsubsection{Kebijakan Segregasi oleh Belanda}

Pemerintah Belanda memiliki pandangan negatif terhadap Islam yang berkembang di Indonesia. Menurutnya, Islam adalah ancaman utama eksistensi mereka. Sehingga orang Arab sebagai bangsa yang membawanya dianggap sebagai musuh utama (Algadri, 1984).

Berdasar artikel di Koloniaal Verslag tahun 1902 (dalam Algadri, 1984), dituliskan bahwa orang Arab adalah golongan yang paling berbahaya bagi ketentraman jajahan Belanda. Mereka dianggap sebagai penghasut yang mengganggu keamanan dan memunculkan kerusuhan. Dituliskan pula, bahwa perlawanan terhadap Belanda di Halmahera, Kalimantan, Aceh, Lombok, Cilegon, dan seluruh Pulau Jawa dianggap dikobarkan oleh orang Arab.

Ketakutan akan munculnya perlawanan di Surakarta terlihat dengan dibangunnya Benteng Vastenburg. Berdasar analisis oleh Hernowo (2015), benteng ini diperkirakan dibangun pada 1832, sedangkan dituliskan oleh Sajid (1984) bahwa benteng ini dibangun dari tahun

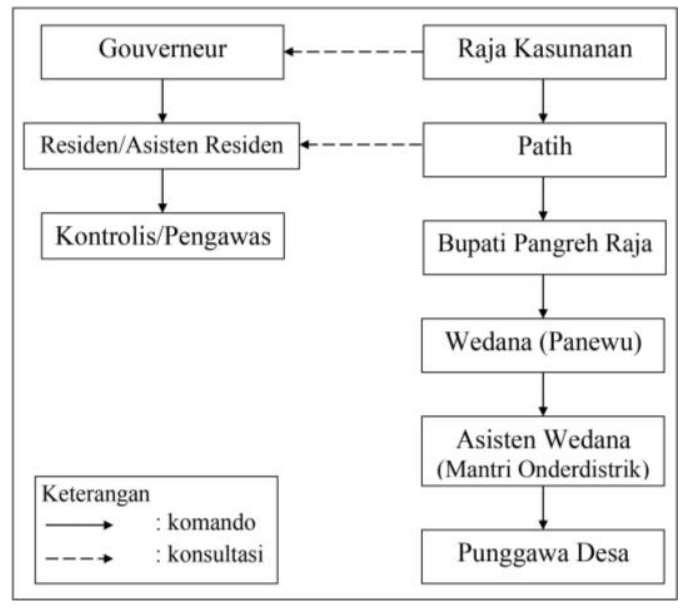

Gambar 6. Struktur pemerintahan diSura karta pada masa Pakubuwono X

Sumber: Serat Wewatoning Para Abdi Dalem Ageng Alit ing Na gari Jawi. Solo: Arsip Mangkunegaran 
1775 hingga 1779. Benteng ini digunakan oleh pemerintah Belanda untuk mengawasi Keraton Kasunanan, permukiman Arab, dan Pecinan, serta interaksi diantaranya.

Ketakutan tersebut juga menyebabkan pemerintah Belanda membuat kebijakan berupa sistem hukum segregasi (pemisahan). Kebijakan ini membagi masyarakat menjadi tiga kategori rasial, yaitu Eropa, asing oriental, dan pribumi. Kategori asing oriental terdiri dari imigran Hadrami, Cina, India, dan negara Asia lainnya (Kesheh, 2007).

Politik segregasi oleh Belanda menjadi lebih ketat mulai tahun 1863. Diberlakukan kebijakan wijken stelsel, yaitu golongan asing oriental (etnis Cina dan Arab) harus tingg al di kampung khusus etnisnya yang terpisah dengan etnis lain, dan kebijakan passen stelsel, yaitu etnis asing tersebut harus menggunakan kartu jalan khusus tiap kali keluar-masuk kawasannya. Kebijakan ini tidak dicabut sampai dekade kedua abad ke-20 (Berg, 2010). Hal ini merupakan upaya politik pemerintah Belanda untuk mengontrol masyarakat, karena ketakutan akan munculnya kesadaran dan gerakan apabila terjadi pembauran antar etnis.

Pembauran dengan keturunan Arab sangat ditentang oleh Belanda dan dianggap sebagai tindak kriminal (Algadri, 1984). Adanya kebijakan segregasi, meningkatkan rasa kesenjangan dan perbedaan secara rasial antara Hadrami dengan pribumi (Kesheh, 2007) Kebijakan ini juga menjadi alat Belanda untuk mempraktikkan politik adu domba (devide et empera) kepada antar etnis.

Migrasi Hadrami ke Indonesia sangat dipersulit oleh pemerintah Belanda dengan adanya berbagai aturan. Sulit bagi imigran untuk mendapat izin menetap. Bahkan setelah mendapat izin pun mereka hanya boleh menetap di kota dan wilayah tertentu saja. Dituliskan oleh Snouck, seorang Islamolog dan penasihat kolonial, di surat rahasia kepada Gubernur Jenderal, bahwa larangan imigrasi orang Arab dikarenakan alasan politik (Algadri, 1984).

Walaupun Belanda mempersulit migrasi dan kependudukan Hadrami di Indonesia, namun melihat Tabel 1, jumlah penduduk asli Arab dan keturunan Arab-Indonesia di Nusantara pada masa kolonial kian bertambah dalam jumlah yang signifikan. Dijelaskan Bisri A. (dalam Saefullah, 2013), selain karena ekonomi di Hadramaut dan mudahnya transportasi berkat revolusi industri, besarnya arus migrasi tersebut dikarenakan adanya kebijakan ekonomi oleh pemerintah Belanda, yang menjadikan etnis Arab dan Cina sebagai perantara perdagangan internasional di Indonesia.

\subsubsection{Korelasi dengan Kondisi Aktual}

Korelasi kondisi aktual dengan sejarah kebijakan Belanda terhadap orang Arab di Indonesia, khususnya di Surakarta, dapat ditemukan dengan menyoroti 3 hal. Hal pertama yang disoroti adalah bukti kekuasaan Belanda di Surakarta, berupa bangunan bekas benteng dan permukiman Belanda. Sudah disebutkan sebelumnya bahwa permukiman Belanda berada di kawasan Lojiwetan. Nama tersebut berasal dari kata loji (bahasa Belanda : loge, berarti rumah) yaitu sebutan rumah Belanda, dan wetan (bahasa Jawa) yang berarti timur, menjelaskan bahwa permukiman Belanda berada di timur benteng. Arsitektur bekas rumah Belanda masih dapat dilihat di kawasan Lojiwetan hingga sekarang.

Di barat Lojiwetan terdapat Benteng Vastenburg peninggalan Belanda. Seperti yang dijelaskan sebelumnya, benteng ini digunakan untuk mengawasi Keraton Kasunanan, permukiman Arab, dan permukiman Cina. Melihat kondisi eksisting di mana sisi barat daya benteng adalah kawasan keraton, di sisi selatan adalah Kampung Arab, dan di sisi utara adalah Pecinan, menguatkan pernyataan bahwa Belanda membangun benteng untuk mengawasi ketiga kubu tersebut (lampiran 5).

Hal kedua yang disoroti adalah pemetaan rumah tua etnik Arab. Keberadaan Belanda di Surakarta berpengaruh pada arsitektur rumah tinggal bangsawan dan saudagar kaya terdahulu, termasuk etnis Arab. Gaya arsitekturnya berupa akulturasi budaya pribumi yang meniru tata cara hidup Belanda, yang dikenal dengan landhuis dan atau indies (akulturasi arsitektur vernakular Jawa). Rumah

Tabel 1. Sensus penduduk Arab dan keturunan Arab di Indonesia pada masa kolonial

\begin{tabular}{|l|c|c|c|c|c|c|}
\hline \multirow{2}{*}{ Wilayah } & \multicolumn{5}{|c|}{ Tahun Sensus } \\
\cline { 2 - 8 } & $\mathbf{1 8 5 9}$ & $\mathbf{1 8 7 0}$ & $\mathbf{1 8 8 5}$ & $\mathbf{1 9 0 0}$ & $\mathbf{1 9 2 0}$ & $\mathbf{1 9 3 0}$ \\
\hline Indonesia & 7.786 & 12.412 & 20.501 & 27.399 & 44.902 & 71.355 \\
\hline Jawa \& & 4.992 & 7.495 & 10.888 & - & - & - \\
Madura & & & & & & \\
\hline Luar Pulau & 2.776 & 4.917 & 9.613 & - & - & - \\
\hline Surakarta & - & 42 & 71 & - & - & - \\
\hline
\end{tabular}

Sumber: Berg, 1886 dalam Kesheh, 2007 
tua etnik Arab di Pasar Kliwon menunjukkan akulturasi arsitektur tropis, Arab, dan Belanda (Bazher, 2018). Berdasar pemetaan (lampiran 6), terlihat pola di mana rumah-rumah tersebut berada di satu kawasan. Secara tidak langsung, hal ini menangguhkan adanya kebijakan pemukiman etnis Arab di masa kolonial.

Hal terakhir yang disoroti adalah penggunaan pagar tinggi dan tertutup pada rumah etnik Arab di Surakarta. Adu domba antara etnis Arab dengan pribumi oleh Belanda dahulu, masih berpengaruh bahkan setelah kemerdekaan. Sekitar tahun 1970, terjadi beberapa kali konflik akibat perasaan saling curiga antara komunitas etnis Arab dengan pribumi di Surakarta (Hastuti, 2008). Diperkeruh lagi oleh peristiwa kerusuhan Mei 1998 di Surakarta, dengan etnis minoritas menjadi korbannya. Akibatnya orang Arab di Surakarta kini menggunakan pagar tinggi dan tertutup di sekeliling rumah. Sedangkan, kondisi berbeda terlihat pada rumah tua etnik Arab di Surakarta yang mayoritas aslinya tidak berpagar depan dan atau berpagar pendek (Bazher, 2017). Hal ini menyiratkan adanya degradasi rasa aman pada etnis Arab di Solo, dari masa lampau dibanding sekarang.

Kajian mengenai peninggalan pemerintah Belanda menguatkan adanya kekuasaan Belanda dahulu di Surakarta. Kajian pemetaan rumah tua etnik Arab menangguhkan adanya kebijakan kuat pengelompokkan permukiman etnis asing di Surakarta. Dari kajian sejarah kekuasaan Belanda di Surakarta dan kebijakan segregasinya, dapat disimpulkan bahwa kebijakan Belanda menjadi salah satu faktor kuat terbentuknya permukiman etnis Arab di Surakarta. Melihat kebijakan wijkenstelsel yang mulai diterapkan pada tahun 1863, maka kebijakan ini berlangsung setelah kebijakan tata ruang kota dari keraton. Pengaruh Belanda masih berbekas hingga sekarang berupa kekhawatiran etnis Arab yang akhirnya menggunakan pagar tinggi pada rumahnya.

\section{KESIMPULAN}

Fenomena terbentuknya tata ruang kota, dipengaruhi oleh berbagai faktor dari luar dan dari dalam masyarakat itu sendiri. Begitu pun dengan terbentuknya Kampung Arab Pasar Kliwon di Surakarta. Berdasar hasil kajian sejarah dan verifikasi dengan kondisi aktual, keempat teori mengenai faktor terbentuknya
Kampung Arab Pasar Kliwon cukup valid kebenarannya. Aktivitas ekonomi, komunitas, kebijakan keraton, dan kebijakan kolonial Belanda, secara berurutan berdasar kronologinya menjadi faktor terbentuknya Kampung Arab di Surakarta. Kondisi di Surakarta diasumsikan sama dengan beberapa daerah di Indonesia.

Kebijakan oleh Keraton Kasunanan dan Belanda hanya berlaku dan berpengaruh pada masa kekuasaan masing-masing (lampiran 7). Sedangkan faktor aktivitas ekonomi dan hubungan komunitas berpengaruh terhadap perkembangan Kampung Arab Pasar Kliwon hingga saat ini. Wilayah Kampung Arab di Surakarta yang dahulu hanya mencakup Kelurahan Pasar Kliwon dan Kedung Lumbu, kini bertambah hingga Kelurahan Semanggi dan Joyosuran, dan masih terus berkembang.

\section{REFERENSI}

Algadri, Hamid. 1984. C Snouck Hurgronje, Politik Belanda terhadap Islam dan Keturunan Arab. Jakarta: Sinar Harapan.

Aliyah, I., Bambang S., Wisnu P. 2015. Eksistensi Pasar Tradisional dalam Kearifan Budaya Jawa. Dalam Seminar Nasional "Menuju Arsitektur dan Ruang Perkotaan yang Ber-kearifan Lokal" PDTAP

Bazher, Najmi Muhamad. 2017. "Konsep Perencanaan dan Perancangan Living Museum Kampung Arab sebagai Wadah Kebudayaan di Pasar Kliwon dengan Pendekatan Sense of Place", Laporan Tugas Akhir. Jurusan Arsitektur. UNS. . 2018. "Rumah Tua Etnik Arab di Kampung Arab Pasar Kliwon sebagai Hasil Akulturasi”, dalam Arsitektura Vol 16, No.1.

Berg, L.W.C. van den. 2010. Orang Arab di Nusantara. Jakarta : Komunitas Bambu.

Bulkia, Aulia Ayu Riandini 2012. "Pola Pergerakan Masyarakat Etnis Arab di Surakarta:Studi Kasus Kecamatan Pasar Kliwon". FMIPA UI, Jakarta.

Denzin, N. K. 1970. The Research Act. Chicago, IL: Aldine.

Hakim, C. 1982. Secondary Analysis of Social Research. London: George Allen \& Unwin. 
Hastuti, F.E. 2008. "Potensi dan Pengembangan Kampung Etnik Arab sebagai Aset Wisata di Surakarta", Laporan Tugas Akhir. FSSR, UNS.

Hernowo, Bimo. 2015. "Studi tentang Lokasi Benteng-Benteng di Surakarta (1672, 1743, 1756, 1832)", dalam ATRIUM, Vol. 1, No. 1.

Karjoko, L. 2005. "Budaya Hukum Keraton Surakarta dalam Pengaturan Tanah Baluwarti sebagai Kawasan Cagar Budaya". Tesis. Ilmu Hukum. UNDIP.

Kesheh, Natalie Mobini. 2007. Hadhrami Awakening Kebangkitan Hadhrami Indonesia. Jakarta : Akbar.

Kurniawan. R. 2011. "Tanah di Keraton Surakarta (Studi Sosiologi mengenai Konflik atas Kepemilikan danPenguasaan Tanah di Lingkungan Keraton Surakarta)" dalam Jurnal Ilmu Administrasi Publik Universitas Brawijaya, Edisi 6 No.1.

Kusumastuti. 2016a. "Pengaruh Budaya dalam Pembentukan Ruang Kota Sala Sejak Perpindahan Kraton Sampai dengan Peletakan Motif Dasar Kolonial”, dalam Region, Vol. 1, No. 1. 2016b. "Proses dan Bentuk Mewujudnya Kota Solo Berdasarkan Teori City Shaped Spiro Kostof" dalam Region, Vol. 1, No. 1.

Kusumo, D.A., Widyawati, Maria H.D.S. 2013. "Perkembangan Struktur Ruang dan Identitas Kota Surakarta Tahun 1745 -1945". Hasil Penelitian. FMIPA, UI.

Moleong, L. 2007. Metode Penelitian Kualitatif. Bandung : PT Remaja Rosda Karya.

Muhafizga. 2014. "Gerakan Anti-Swapraja di Daerah Istimewa Surakarta 1945-1946", https://hafizsejarah.wordpress.com/2014 /06/24/gerakan-anti-swapraja-di-daerahistimewa-surakarta-1945-1946/ [Diakses pada 1 Juli 2020].

Mulyadi, M. H. 1999. Runtuhnya Kekuasaan

"Kraton Alit": Studi Radikalisasi Sosial

"Wong Sala" dan Kerusuhan Mei 1998 di Surakarta. LPTP Surakarta.

Prasetyo, H. 2001. "Wajah Kauman Surakarta 1910-1930", Skripsi. FIB, UGM.

Priyatmoko, H. 2017 Maret 7. "Historiografi (Keturunan) Arab di Solo". Joglosemar. Opini : 9

Putri, R.H. "Hak dan Kewajiban Raja sebagai Titisan Dewa", https://historia.id/kuno/ articles/hak-dan-kewajiban-raja-sebagaititisan-dewa-vQJJB [Diakses pada 25 Juni 2020].

Qomarun dan Budi Prayitno. 2007. "Morfologi Kota Solo (Tahun 1500-2000)", dalam Dimensi Teknik Arsitektur Vol. 35 No.1.

Ridwiyanto, A. 2011. "Batavia sebagai Kota Dagang pada Abad XVII sampai Abad XVIII". Skripsi. Fakultas Adab dan Humaniora. UIN Syarif Hidayatullah.

Rosiana, B.R. 2013. "Terbentuknya Birokrasi Modern di Surakarta Tahun 1945-1950". Skripsi. Jurusan Ilmu Sejarah. UNS.

Saefullah, H. 2013. "Kaum Arab-Hadrami di Indonesia: Sejarah dan Dinamika Diasporanya”, https://antimateri.com/ kaum-arab-hadrami-di-indonesia-sejarah -dan-dinamika-diasporanya-1/\#/ [Diakses 17 Juni 2020].

Sajid, R.M. 1984. Babad Sala. Perpsutakaan Istana Mangkunegaran, Solo.

Santoso, J. 1984. "Konsep Struktur dan Bentuk Kota di Jawa s/d Abad XVIII". Dalam Junianto. 2019. "Konsep MancapatMancalima dalam Struktur Kota Kerajaan Mataram Islam Periode Kerajaan Pajang sampai dengan Surakarta", dalam Mintakat, Vol. 20, No.2

Setiawati, N.A. 2011. Dari Tanah Sultan menuju Tanah Rakyat. Yogyakarta : STPN Press

Soemardjan, Selo. 1981. Perubahan Sosial di Yogyakarta. Dalam Zaenurrosyid, A. 2013. "Maridjan Menang Taruhan (Analisis Antropologis terhadap Pertarungan Agama-Budaya Maridjan pada 2006)" dalam Analisa Vol. 20, No. 2

Suryono, S.J. dan Aji Wiyoko. 2015. "Peleburan Tradisional Pasir Besi Bengawan Solo dan Pasir Besi Merapi untuk Bahan Baku Besi Keris dan Pamor Keris". Hasil Penelitian. ISI Surakarta.

Tibbetts, G.R. 1956. "Pre-Islamic Arabia and South-East Asia", dalam Journal of the Malayan Branch of the Royal Asiatic Society Vol. 29, No. 3

Zaida, S.N.A. dan Nurhayati H.S.Arifin. 2010. "Surakarta: Perkembangan Kota sebagai Akibat Pengaruh Perubahan Sosial pada Bekas Ibukota Kerajaan di Jawa", dalam Jurnal Lanskap Indonesia, Vol. 2, No. 2. 


\section{LAMPIRAN}

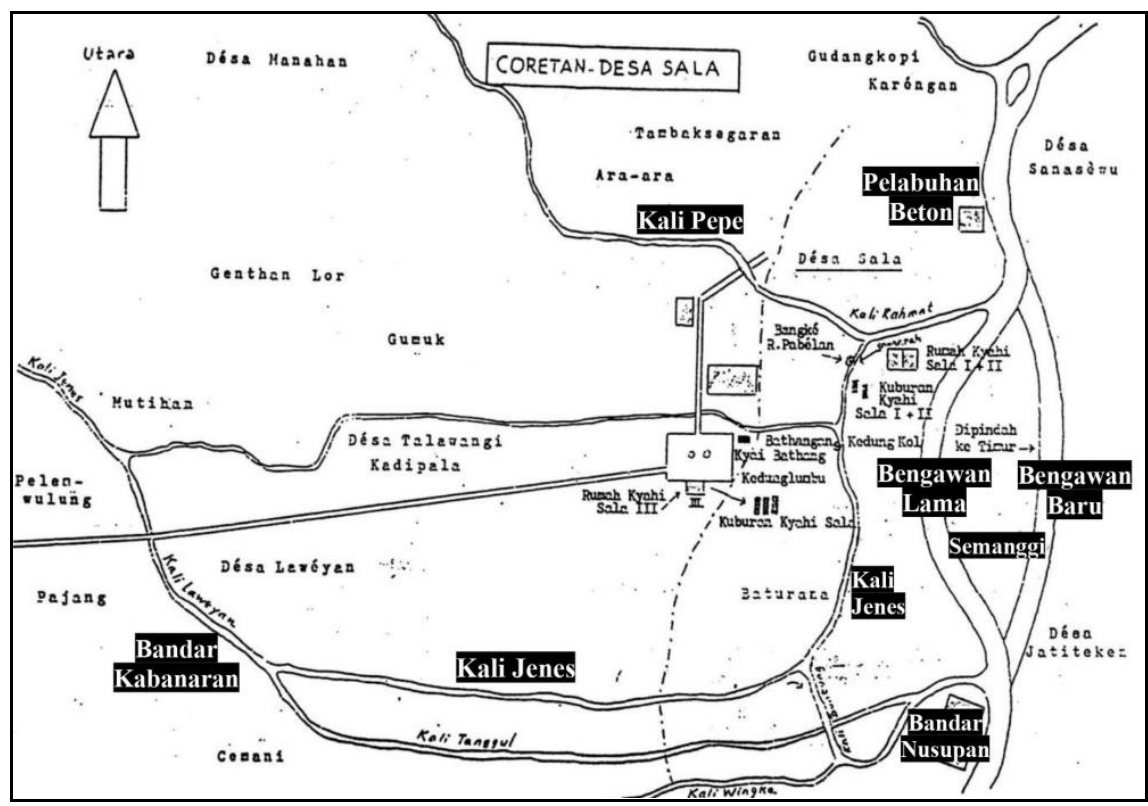

Lampiran 1. Peta alira n sungai da n bandar dagang di Sura karta Sumber: Sajid, 1984

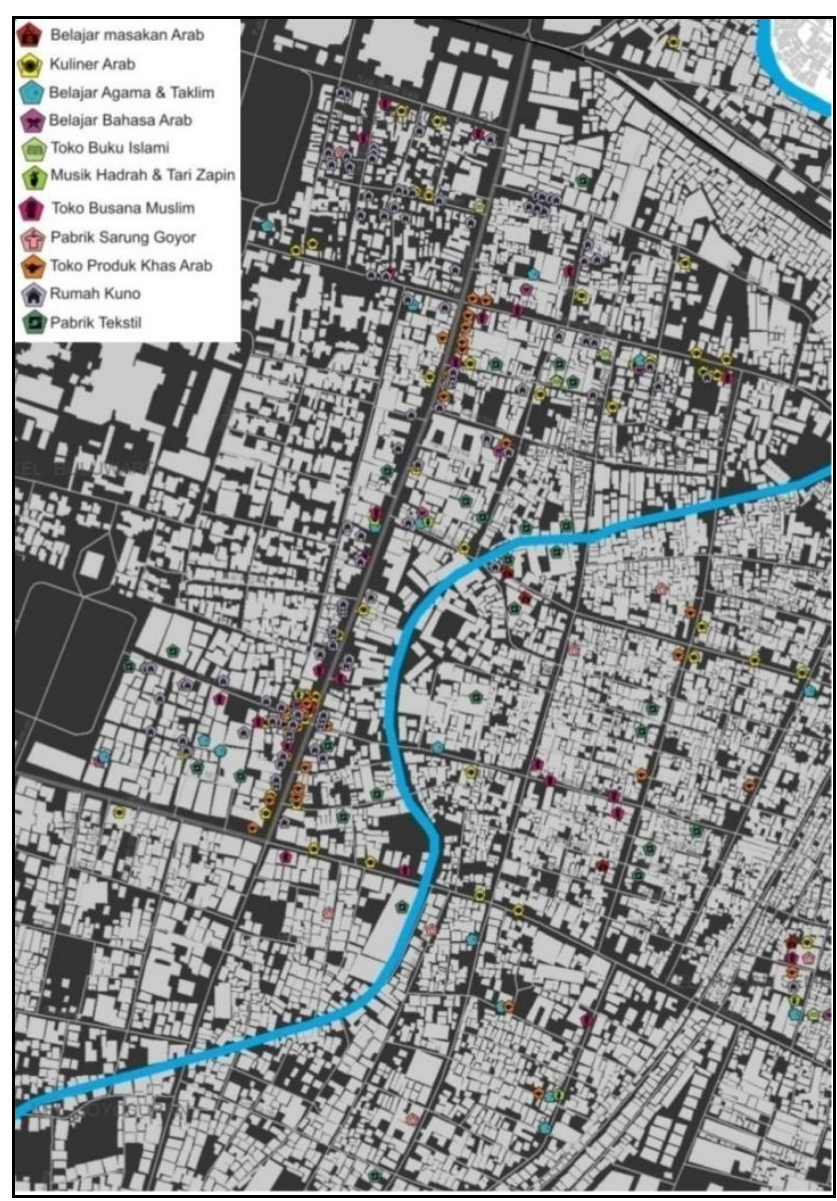

Lampiran 2. Pemetaan aktivitas ekonomi etnis Arab di Kampung Arab Pa sar Kliwon Sumber: DTRK Surakarta, diolah kembali oleh Bazher, 2020 


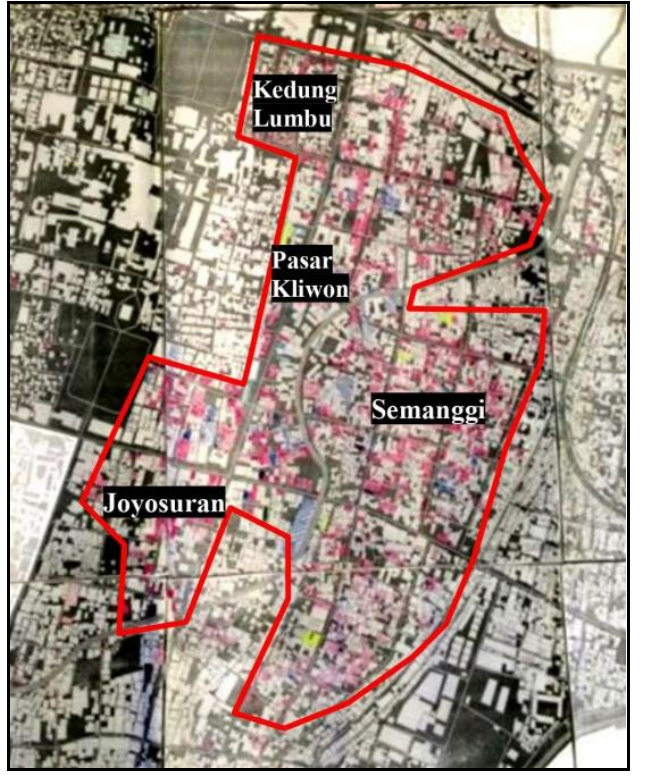

Lampiran 3. Pemetaan permukiman etnis Arab di Ka mpung Arab Pasar Kliwon

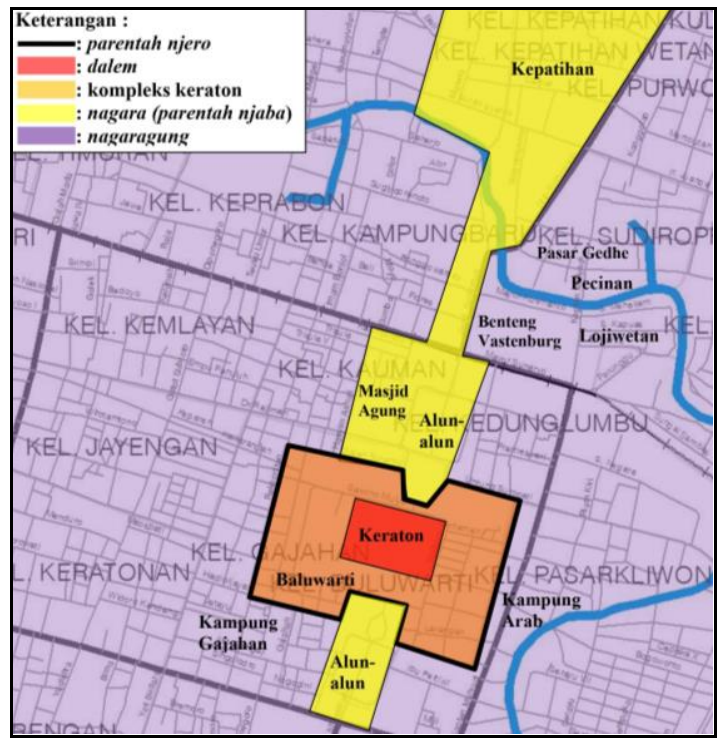

Lampiran 4. Pemetaan tata Kota Surakarta berdasar kebijakan Keraton Kasunanan Sumber:DTRK Surakarta, diolah kembalioleh Bazher, 2020

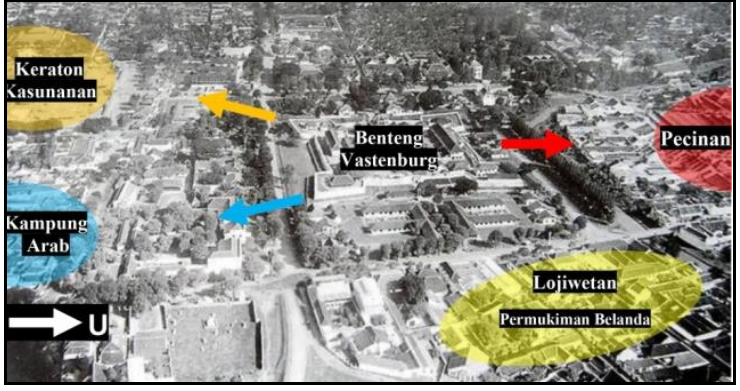

Lampiran 5. Lokasi Benteng Vastenburg dapat melihat ke keraton, Kampung Arab, dan Pecinan Sumber:httpstumpi.idbeteng-vastenburg-ruangseni-terbuka-di-kota-solo, diolah kembalioleh Bazher, 2020

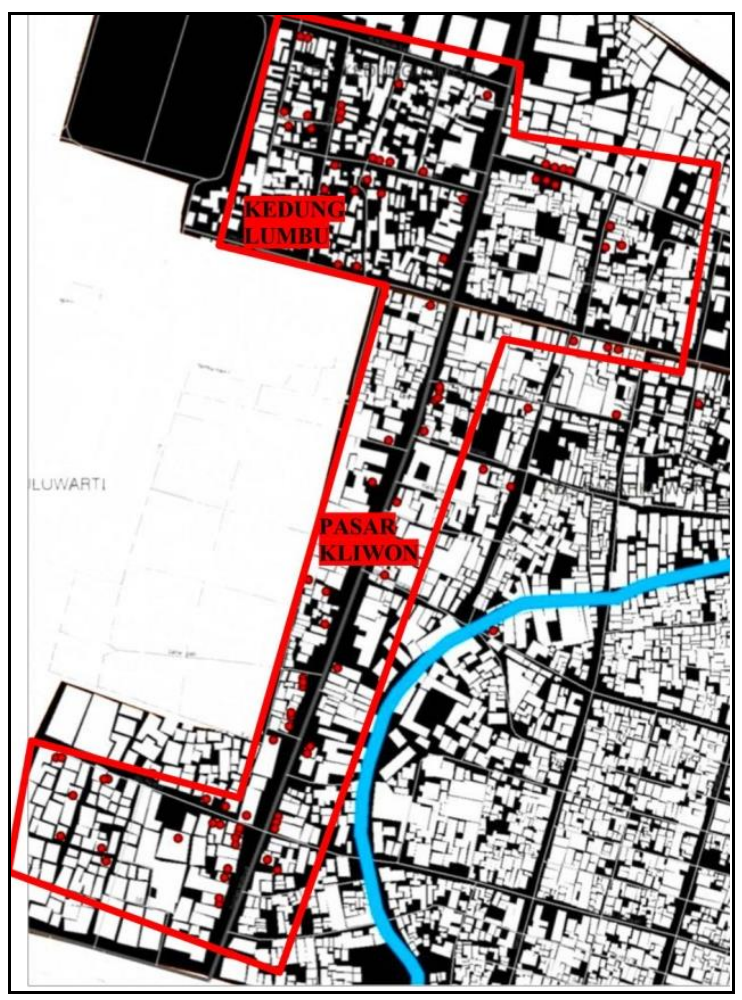

Lampiran 6. Pemetaan rumah tua etnis Arab di Kampung Arab Pasar Kliwon

Sumber:DTRK Surakarta, diolah kembali oleh Bazher, 2020

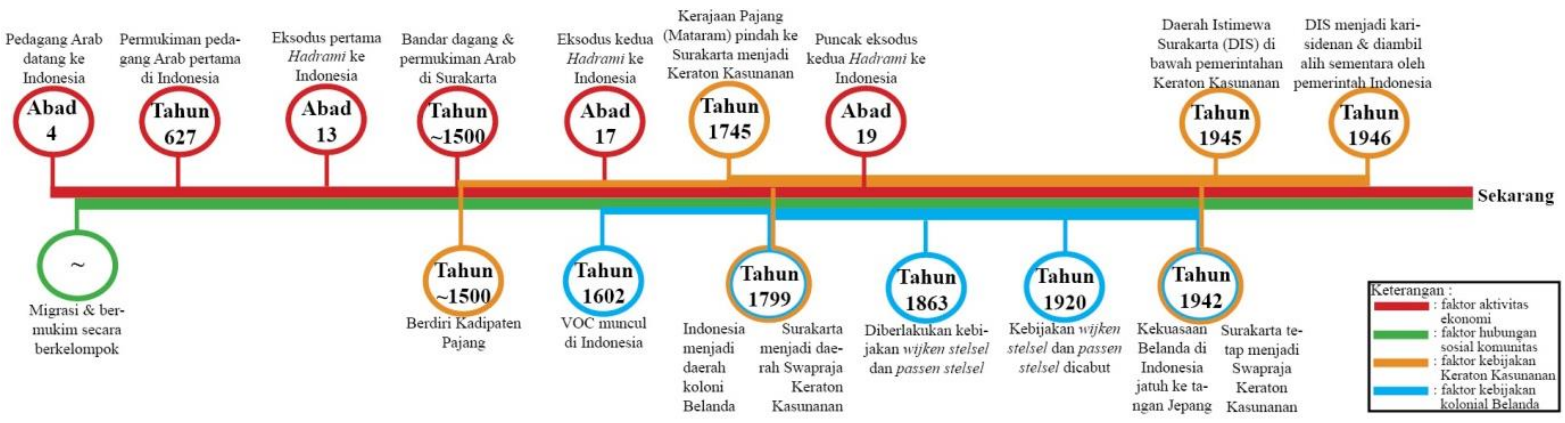

Lampiran 7. Lini waktu faktor terbentuknya Kampung Arab Pa sar Kliwon di Surakarta 